\title{
COL4A5 Gene
}

National Cancer Institute

\section{Source}

National Cancer Institute. COL4A5 Gene. NCI Thesaurus. Code C71433.

This gene is involved in the determination of the structure of the extracellular matrix. 